Please do not remove this page

RMIT

UNIVERSITY

\title{
A voluntary approach to designing for safer construction
}

Lingard, Helen; Wakefield, Ronald

https://researchrepository.rmit.edu.au/esploro/outputs/9921859517701341/filesAndLinks?institution=61RMIT_INST\&index=null

Lingard, H., \& Wakefield, R. (2013). A voluntary approach to designing for safer construction. Proceedings of Institution of Civil Engineers: Management, Procurement and Law, 166(5), 249-259.

https://doi.org/10.1680/mpal.12.00015

Document Version: Accepted Manuscript

Published Version: https://doi.org/10.1680/mpal.12.00015

Repository homepage: https://researchrepository.rmit.edu.au

(C) ICE Publishing

Downloaded On 2023/04/27 00:15:01 +1000

Please do not remove this page 
Thank you for downloading this document from the RMIT Research Repository.

The RMIT Research Repository is an open access database showcasing the research outputs of RMIT University researchers.

RMIT Research Repository: http://researchbank.rmit.edu.au/

\section{Citation:}

Lingard, $\mathrm{H}$ and Wakefield, R 2013, 'A voluntary approach to designing for safer construction', Proceedings of Institution of Civil Engineers: Management, Procurement and Law, vol. 166, no. 5, pp. 249-259.

See this record in the RMIT Research Repository at:

https://researchbank.rmit.edu.au/view/rmit:26071

Version: Accepted Manuscript

Copyright Statement: @ ICE Publishing

Link to Published Version:

http://dx.doi.org/10.1680/mpal.12.00015 


\title{
A voluntary approach to designing for safer construction
}

\author{
Helen Lingard and Ron Wakefield
}

\begin{abstract}
Preventing occupational health and safety (OHS) hazards through design is consistent with the principle that OHS is best managed by eliminating hazards at their 'source' rather than reducing risks that eventuate in the workplace. In 2007, an industry-initiated research and development project was undertaken in Australia to identify and document best practices used in the management of OHS in the construction industry, resulting in the publication of a 'Guide to Best Practice for Safer Construction.' The project was a whole industry effort to identify OHS 'best practices' through the project lifecycle. The guide provides an industry-agreed framework for clients, designers and constructors, with an emphasis on cooperation, communication and reaching consensus about a reasonable allocation of responsibility for OHS in a given project situation. Two years since the publication of the guide, the implementation of the design stage best practices is examined. Three case study projects (a large road construction project, a desalination plant and a high rise building project) are used to illustrate the practical impact of considering the OHS of construction workers in design decision-making in accordance with the 'Safer Construction' principles contained in the guide.
\end{abstract}

\section{Key words}

Occupational Health and Safety, Construction Hazard Prevention through Design, Project Management, Australia.

\section{Introduction}

\section{Safety in Australia's construction industry}

Relative to other industries, the occupational health and safety (OHS) performance of the Australian construction industry is poor. Australian construction workers are approximately twice as likely to be killed at work than workers in other industries. The most recent data published by SafeWork Australia (2010) show the construction industry fatality rate is 5.6 per 100,000 workers, compared with an industry average of 2.4. Since 2003/04, 233 compensated fatalities have been recorded in the construction industry, representing an average of 46.6 per year. Preliminary data for 2007-08 financial year also show that there were 14,410 serious workers' compensation claims during this period, representing $10.7 \%$ of claims across all industries. This places the construction industry as the fourth most represented industry in Australia in terms of incidence of compensated work-related injury or disease. The incidence rate ${ }^{1}$ for construction is 21.6 per 1,000 employees, behind manufacturing (24.1 per 1,000 employees), transport and storage (24.4 per 1,000 employees), and agriculture, forestry and fishing (24.3 per 1,000 employees). These compensation-based statistics are also considerably lower than those published by the Australian Bureau of Statistics (ABS). Using data collected in the Multi-Purpose Household Survey (MPHS) conducted in 2005 - 2006, the construction industry had an incidence rate of 86 per 1,000 employed people. $^{2}$

\section{Prevention through Design}

There is considerable evidence that the design of buildings/structures can contribute to 'downstream' OHS incidents in the construction stage (Behm, 2005, Gibb et al. 2004; Gambatese et al. 2008). In Australia, Driscoll et al. (2008) suggest $44 \%$ of construction fatalities are related to design. The twenty first century has seen the notion of 'prevention through design' (PtD) gain international prominence. The $\mathrm{PtD}$ initiative is based on the belief that the best way to prevent and control OHS risks is to eliminate hazardous features of a product or process at the design stage (Manuele, 2008). PtD is consistent with the 'hierarchy of control' by which technological risk controls (i.e., those involving the elimination of a hazard; the substitution of a hazardous process or product with one that is less hazardous; or the provision of an engineering solution to OHS risk) are preferable to controls that rely upon human behaviour for their effectiveness. Underpinning the case for $\mathrm{PtD}$ is the argument that the greatest opportunity to reduce

\footnotetext{
${ }^{1}$ The incidence rate of occupational injuries and diseases is the number of claims expressed as a rate per thousand employees.

2 This difference is largely due to the fact that the ASCC relies solely on workers' compensation claims data and excludes selfemployed persons. The ABS dataset includes non-fatal injuries or illnesses sustained by all categories of workers, irrespective of whether these have been claimed under workers' compensation.
} 
OHS risk exists during the design stage and, therefore, proactively eliminating a hazard 'at source' is preferable to reactively managing an OHS risk at the worksite (Toole, 2005).

\section{OHS policy in Australia}

In recent years the PtD philosophy has been integrated into a number of important policy initiatives in Australia. For example, 'safe design' was a priority element of the National OHS Strategy 2002-2012 (NOHSC, 2002) and has since been the focus of significant effort to attain national consistency in OHS policy and regulation (Creaser, 2008). Building on the National OHS Strategy, a National Standard for Construction Work was developed in 2005 (NOHSC, 2005). The National Standard established clear OHS recommendations for construction designers. Specifically, the National Standard suggested that designers:

(i) ensure that hazards associated with the construction work required by the design are identified before the commencement of construction work;

(ii) ensure, to the extent that they have control over the design, that any risks to the health and safety of any person affected by the construction work are eliminated, or where this is not reasonably practicable, minimised; and

(iii) report to the client, in writing, on the health and safety aspects of the design.

The National Standard also states that the level of detail to be provided in the designers' report must be commensurate with the degree of risk identified by the designer.

\section{OHS legislation}

OHS legislation in Australia is the responsibility of each state and territory. Thus far, seven states and territories have incorporated specific duties for the designers of building and structures into their principal OHS Acts. The legislated requirements are summarised in Table 1.

\section{Table 1: States and territories that have incorporated specific duties for designers of} buildings/structures into their principal OHS Acts.

\begin{tabular}{|c|c|}
\hline State & Requirement \\
\hline $\begin{array}{l}\text { Western } \\
\text { Australia }\end{array}$ & $\begin{array}{l}\text { The Occupational Safety and Health Act } 1984 \text {, Section } 23(3 \mathrm{a}) \text { requires: } \\
\text { A person that designs or constructs any building or structure, including a temporary } \\
\text { structure, for use at a workplace shall, so far as is practicable ensure that the design and } \\
\text { construction of the building or structure is such that: } \\
\text { (a) persons who properly construct, maintain, repair or service the building or structure; } \\
\text { and } \\
\text { (b) persons who properly use the building or structure are not, in doing so, exposed to } \\
\text { hazards. }\end{array}$ \\
\hline Queensland & $\begin{array}{l}\text { The Workplace Health and Safety Act 1995, Section 30B establishes that: } \\
\text { (1) A designer of a structure has an obligation to ensure the design of the structure does not } \\
\text { affect the workplace health and safety of persons-- } \\
\text { (a) during construction of the structure; and } \\
\text { (b) when the structure has been constructed and is being used for the purpose for which } \\
\text { it was designed. } \\
\text { (2) The obligation is discharged if persons are not exposed to risks to their health or safety } \\
\text { arising out of the design. } \\
\text { (3) For deciding, after the structure has been designed, whether the designer discharged the } \\
\text { designer's workplace health and safety obligation under subsection (1), regard must be had } \\
\text { to the standards of design prevailing when the designer designed the structure. } \\
\text { (4) The designer's obligation under subsection (1) applies only to the extent that the content } \\
\text { of the design of the structure falls under the control of the designer. } \\
\text { (5) In this section, structure does not include a structure that is a class 1a building or an } \\
\text { associated class 10a building. }\end{array}$ \\
\hline $\begin{array}{l}\text { South } \\
\text { Australia }\end{array}$ & $\begin{array}{l}\text { The Occupational Health, Safety and Welfare Act 1986, Section } 23 \text { A establishes that: } \\
\text { (1) A person who designs a building that is reasonably expected to comprise or include a } \\
\text { workplace must: }\end{array}$ \\
\hline
\end{tabular}




\begin{tabular}{|c|c|}
\hline & $\begin{array}{l}\text { (a) ensure so far as is reasonably practicable that the building is designed so that people } \\
\text { who might work in, on or about the workplace are, in doing so, safe from injury and } \\
\text { risks to health; and } \\
\text { (b) ensure that the building complies in all respects with prescribed requirements (if } \\
\text { any) applicable to it. } \\
\text { For the purposes of this section 'building' includes parts of a building. } \\
\text { Further, Section } 24 \text { (2)(a)(a) states that: } \\
\text { Where any structure is to be erected in the course of any work, the person who designs the } \\
\text { structure must ensure so far as is reasonably practicable that the structure is designed so that } \\
\text { the persons who are required to erect it are, in doing so, safe from injury and risks to health. }\end{array}$ \\
\hline Victoria & $\begin{array}{l}\text { Section } 28 \text { of the Occupational Health and Safety Act } 2004 \text { requires that: } \\
\text { (1) A person who designs a building or structure or part of a building or structure who } \\
\text { knows, or ought reasonably to know, that the building or structure or the part of the } \\
\text { building or structure is to be used as a workplace must ensure, so far as is reasonably } \\
\text { practicable, that it is designed to be safe and without risks to the health of persons using it } \\
\text { as a workplace for a purpose for which it was designed. }\end{array}$ \\
\hline Tasmania & $\begin{array}{l}\text { Section 14(1) of the Workplace Health and Safety Act } 1995 \text { establishes that: } \\
\text { A person who designs, manufactures, imports or supplies any plant or structure for use at a } \\
\text { workplace must so far as is reasonably practicable - } \\
\text { (a) ensure that the design and construction of the plant or structure is such that persons } \\
\text { who use the plant or structure properly are not, in doing so, exposed to risks to their } \\
\text { health and safety; and } \\
\text { (b) when the plant or structure is supplied, ensure that adequate information is supplied } \\
\text { in respect of - } \\
\text { (i) any dangers associated with the plant or structure; and } \\
\text { (ii) the conditions necessary to ensure that persons using the plant or structure } \\
\text { properly are not, in doing so, exposed to risks to their health and safety. }\end{array}$ \\
\hline ACT & $\begin{array}{l}\text { Section } 24 \text { of the Work Safety Act } 2008 \text { establishes responsibilities for persons in control of } \\
\text { the design of plant or structures as follows: } \\
\text { (1) This section applies to a person in control of- } \\
\text { (a) the design of plant or a structure that is used, is to be used or could reasonably be } \\
\text { expected to be used, at work or at a workplace; or } \\
\text { (b) the design of a structure that is, is to be or could reasonably be expected to be, a } \\
\text { workplace. } \\
\text { (2) The person has a duty to ensure work safety in relation to the design of the plant or } \\
\text { structure by managing risk. }\end{array}$ \\
\hline $\begin{array}{l}\text { Northern } \\
\text { Territory }\end{array}$ & $\begin{array}{l}\text { Section } 57 \text { of the Workplace Health and Safety Act } 2007 \text { requires: } \\
\text { (1) An employer has a duty to take all reasonably practicable measures to ensure that: } \\
\text { (a) workplace infrastructure or equipment, and workplace materials, are safe; and } \\
\text { (b) workers are, where necessary, properly instructed in the use, and warned about risks } \\
\text { involved in the use, of workplace infrastructure or equipment, and workplace } \\
\text { materials; and } \\
\text { (c) if workplace materials are poisonous - adequate toxicological information is } \\
\text { available. } \\
\text { (2) The duty extends, to the extent that may be appropriate in the circumstances, to a person } \\
\text { who: } \\
\text { (a) owns, designs, constructs, manufactures, imports, installs or supplies workplace } \\
\text { infrastructure or equipment or any component of workplace infrastructure or } \\
\text { equipment; or } \\
\text { (b) designs, manufactures, imports or supplies workplace materials. }\end{array}$ \\
\hline
\end{tabular}

\section{Aims}

Notwithstanding inconsistencies in the regulation of PtD in Australia, the construction design professions have acknowledged the potential for designers to contribute to a reduction in the incidence of workrelated death, injury and illness in the construction industry. This paper describes the industry-led development of a voluntary 'Guide to Best Practice for Safer Construction,' hereafter referred to as 'the 
guide,' which establishes a framework for the integration of OHS into decision-making from the planning to the post-construction stages of construction projects. The paper also examines the implementation of the design stage component of the guide. Three case study projects (a large road construction project, a desalination plant and a high rise building project) are used to illustrate the practical impact of considering the OHS of construction workers in design decision-making in accordance with the 'Safer Construction' framework.

\section{Industry response}

The relatively poor safety performance of the Australian construction industry prompted senior representatives of each of the key stakeholders groups in the construction industry, i.e. clients, designers and constructors, to embark upon a collaborative project to improve the safety performance of the construction industry. The project, titled 'Safer Construction' was commissioned by Engineers Australia and funded by the Cooperative Research Centre for Construction Innovation. A high level industry task force was established to oversee the development of a voluntary guide to best practice in promoting OHS during the planning, design and construction stages of projects. The task force comprised senior representatives of major industry stakeholder groups, industry peak bodies and professional institutions. Represented were: Engineers Australia; the Property Council of Australia; the Australian Procurement and Construction Council; the Association of Consulting Architects Australia; the Association of Consulting Engineers Australia; the Australian Institute of Architects; the Australian Constructors Association; and the Master Builders Association. Also invited to participate in the task force was a representative of the Office of the Federal Safety Commissioner. Thus, the task force was representative of construction clients, the design professions and constructors, as well as government and policy makers.

In bringing together the perspectives of each of these parties (through their respective professional/industry associations), the 'Safer Construction' project provided the basis for moving towards a proactive culture of establishing (on a project-by-project basis) an appropriate allocation of responsibility for OHS during the all stages of project delivery. The objective was not to reduce the responsibility of 'the Constructor' for the OHS of the workers and sub-contractors they employ. Rather, the guide aimed to identify additional measures that could be taken by 'the Client' and 'the Designer' prior to the commencement of construction work that could contribute to the reduction of OHS risks during the construction stage.

The guide comprises a number of documents, tools and checklists. At the heart of the guide is an 'Implementation Table', specifying safety practices to be undertaken during four 'lifecycle' stages of a construction project, i.e., (i) planning; (ii) design; (iii) construction; and (iv) post-construction (commissioning). The guide also establishes six broad principles for the management of OHS within the construction industry. Principle 2 is particularly relevant to the PtD concept, about which the guide states the following:

"Effective safety management at the design stage can minimise risks to the health and safety of people who subsequently construct, occupy and maintain a facility/structure. Consequently, the client should ensure that a designer is engaged who has a demonstrated understanding and awareness of safety risk management or other suitable credentials of safety in design, appropriate to the risks of the project. Often during the design stage, a number of organisations or individuals contribute to the final design, with their contributions being coordinated by a prime design manager - usually a principal designer acting for the client (the designer), or the client itself. In such cases, all organisations and individuals should participate in appropriate risk assessments and safety management decisions appropriate to their sphere of control. Comprehensive and systematic design safety reviews should be conducted at appropriate intervals during the design process. These reviews should be based on appropriate risk management methods. Design safety reviews should be collaborative in nature where possible. Safety risks arising as a result of the design should be eliminated wherever possible or practicable. Where elimination is not possible, efforts to reduce safety risk through design modification should be made. Residual risk, i.e. the identified risks remaining following the design safety risk management process, should be documented 
and clearly communicated to relevant stakeholders - including the client, the constructor, and the owner/occupier - where they would not, or may not, be readily apparent to 'downstream' stakeholders in their own risk assessment." (Fleming et al. 2007a, p. 4).

The Guide also establishes 62 'Best Practice' tasks which should be carried out during four key stages in the life of a construction project. Of these, 14 tasks are specified for the design stage (Fleming et al. 2007b).

\section{Design Stage Implementation}

To support the implementation of the design stage 'Safer Construction' tasks, Engineering Education Australia (a subsidiary of Engineers Australia) commissioned the development of a case study-based training resource kit. The resulting training is being delivered throughout Australia. The materials are based upon three detailed case studies of best practice in PtD in the Australian construction industry. The three case studies are described below.

\section{Case studies}

The three case study projects involved the construction of a desalination plant, the construction of a highrise office building and the upgrade of a major freeway.

\section{Case 1: The desalination plant}

Up to $15 \%$ of Sydney's drinking water can be produced by the desalination of sea water, reaching 1.5 million people as part of their drinking water supply. To achieve this capacity, Sydney Water engaged the Blue Water Joint Venture (hereafter called the 'joint venture') to build a AUS\$1 billion desalination plant at Kurnell in Sydney's southern suburbs. The plant, which is commenced operation in January 2010, can produce 250 million litres of water a day, which can be scaled up to 500 million litres a day in the future. The scope of works for the project included:

- The placement of in excess of 60,000 cubic metres of concrete;

- The installation of 13,500 tonnes of reinforcing steel;

- The fabrication and erection of 3,000 tonnes of structural steel;

- The supply and installation of more than 3,000 mechanical items;

- 150,000 cubic metres of earthworks;

- The construction of more than $32 \mathrm{~km}$ of pipework;

- The supply and installation of 200 pumps; and

- The installation of more than $386 \mathrm{~km}$ of electrical cables and $520 \mathrm{~km}$ of data cables.

As part of the project, a 67-turbine wind farm was built at another location to generate enough renewable energy to offset the energy use of the plant. The wind farm construction was not part of the joint venture's scope of work.

\section{Case 2: The freeway upgrade}

The upgrading of the West Gate Freeway was a major plank in the Victorian State Government's transport plan for Melbourne. The project aimed to increase capacity and improve safety along Melbourne's most heavily trafficked and economically important transport connection. Before the upgrade, the freeway carried up to 160000 vehicles per day - including 20000 trucks. The major objectives of the project were to improve the efficiency of the current freeway infrastructure by eliminating conflicting merging and weaving movements and to increase capacity, thus reducing travel times and improving safety and reliability. These objectives were met by constructing extra collectordistributor lanes in both directions to eliminate the current merging and weaving movements. In addition, the freeway was widened by one lane over most of the length of the project. Prominent features of the project were the construction of a new, elevated west-bound carriageway to carry traffic and the complete redesign of a major interchange. 
The section of freeway covered by the project was a mixture of at-grade and elevated carriageways. The project was nearly $5.5 \mathrm{~km}$ long. The maximum length of the new spans was $53 \mathrm{~m}$ but most spans were between 30 to $40 \mathrm{~m}$. New entry and exit ramps were connected to the elevated carriageways of the main bridges. The upgrade project required the construction of sections of deck that were 'stitched' to the deck of the existing bridges, as well as the construction of free-standing bridges for ramps and distributor roads. The client, VicRoads, chose an alliance contract strategy for the project. Alliance project delivery requires a highly collaborative working relationship between all parties - the client, designers and constructors throughout the project life.

\section{Case 3: The office building}

The Myer National Support Office is a 14-storey commercial development located in the Docklands Harbour Precinct, a small distance west of Melbourne's Central Business District. The Myer National Support Office project was undertaken to provide three floors for car parking, ten floors of commercial office space, a ground floor comprising an entrance lobby and retail tenancies, and a roof-top plant room. The project scope included design and construction, with an integrated fit-out of the tenancy levels.

The project was delivered using a Design and Construct contracting strategy, which was awarded to Lend Lease Development. In the case of this project, the integration of the PtD concept was further enhanced by the close working relationship between the two partner organisations -Lend Lease Design (the designer) and Bovis Lend Lease Limited (the constructor). Both organizations are members of the Lend Lease group of companies and therefore have an aligned culture of safety in their organizations.

\section{PtD management processes}

At all three case study projects, safety aspects of the design were systematically identified and assessed. In the case of the freeway upgrade and desalination plant, a process known as Construction Hazard Assessment Implication Review (CHAIR) was used to identify and assess OHS risks at the conceptual and detailed design stages (WorkCover NSW, 2001). CHAIR uses a broad set of guide words and prompts to steer the designers to consider OHS implications when developing options for the various design elements. The CHAIR process involved consultation with all relevant stakeholder groups, including designers, constructors, end users, maintenance and OHS personnel. CHAIR is a staged process. A CHAIR 1 review is undertaken at the concept design stage to address general OHS and constructability concerns. Issues that cannot be resolved during the CHAIR 1 are recorded as requirements to follow up during the detailed design stage.

At the desalination plant project items minuted during CHAIR reviews were allocated to a Design Work Package and the manager responsible for these packages was then responsible for ensuring that the item of concern was properly considered as the design was further developed. The CHAIR 1 was conducted over two days and was divided up into plant areas. Table 2 provides a breakdown of the CHAIR 1 action items by area and the number of items reviewed. The majority of the OHS issues identified were resolved during the review. 
Table 2: Summary of CHAIR 1 action items.

\begin{tabular}{|l|l|}
\hline Area & $\begin{array}{l}\text { Number of Action } \\
\text { Items }\end{array}$ \\
\hline Marine & 15 \\
\hline Tunnels & 21 \\
\hline Intake pump station & 53 \\
\hline Pre-treatment area & 8 \\
\hline Reverse osmosis building & 10 \\
\hline Chemical storage & 1 \\
\hline Break tank & 2 \\
\hline Drinking water treatment plant & 3 \\
\hline Waste water treatment plant & 8 \\
\hline Total & $\mathbf{1 2 1}$ \\
\hline
\end{tabular}

As the design progressed to the detailed design stage a more in-depth review was performed, referred to as the CHAIR 2 review. CHAIR 2 reviews comprised detailed CHPtD reviews focused on each section of the desalination plant. Eleven workshops were held over a period of two months. A total of 375 items were minuted across the eleven reviews. The purpose of the CHAIR 2 reviews was to identify specific OHS hazards that could arise during the construction of each functional area. For each functional area, proposed hazard mitigation solutions were brainstormed and recorded for consideration and possible incorporation into the design. Subsequently responsibility was assigned to design team members to address the proposed actions and to select and implement an appropriate solution. The design teams' PtD solutions were then reviewed before being 'closed out.' The CHAIR 2 and follow up process resulted in many significant changes in the design of the plant. The output of the reviews was a schedule of proposed actions recorded on the project management information system. These actions were then incorporated into the Design Review Report for the particular Design Work Package.

At the freeway upgrade project the CHAIR process was applied in conjunction with project constructability review meetings. Eighteen constructability review meetings were held with inputs received from designers, site personnel, internal stakeholders and end users to identify OHS issues and identify ways to mitigate hazards during the detailed design phase. A further five CHAIR 1 review meetings were held to discuss the PtD issues in the project. CHAIR 2 and 3 phases continued throughout the detailed design phase, with the design managers meeting in regular workshops. The purpose of these workshops was to identify OHS hazards in the construction, operation and maintenance of the freeway and select appropriate PtD solutions to mitigate identified OHS hazards.

At the office building project a process called Risk and Opportunity at Design (ROAD) was followed. In this process, OHS risks and opportunities for OHS improvements were identified at the design stage. Standard documents were completed prior to the commencement of the ROAD analysis clarifying the roles and responsibilities of the participants. The client and contractors involved in the project were included in the assessment process. The project manager facilitated and chaired the process and was the 'owner' of the ROAD analysis. Participants were selected to ensure their experience and expertise matched the specific requirements of the project. Once project risks and opportunities had been identified, the information was placed into a formal document and distributed to participants for review. The ROAD report then became a 'living' document used throughout the life of the project. It continued to evolve over the project's lifecycle stages. Details of the project were electronically recorded and could be viewed by others in the Bovis Lend Lease organization, even though they might not be involved in the project. The company intranet has a site dedicated to lessons learned during ROAD analyses from which information can be downloaded for others to use as a reference. This facilitates organizational learning with regard to $\mathrm{PtD}$ and the transfer of best practice from project to project. 


\section{PtD technical solutions}

At all three case study projects, a range of PtD solutions was implemented to mitigate OHS hazards during construction. To illustrate the practical OHS benefits of engaging in a systematic PtD process, three examples of technical solutions that were implemented are provided below.

\section{Culvert design at the desalination plant}

At the desalination plant, a series of culverts was designed to house the pipes that feed the Reverse Osmosis (RO) Plant. Fibreglass was chosen as the preferred material for the feeder pipes - to eliminate the considerable risk of corrosion by the sea water. The culverts are located around the perimeter of the building housing the RO Plant (See Figure 1) and one of the OHS issues identified at the preliminary design phase was that the culverts and the RO building were to be built simultaneously.

Access to the building during construction was difficult due to the excavation of the trenches, the construction of the culverts and the installation of the pipes and equipment within the culverts. The design and staging of the construction of the culverts had to consider the potential for the surcharge loading of construction vehicles moving alongside the culverts. This was overcome by creating exclusion zones running adjacent to the culvert to ensure adequate separation between live loading and the trench excavation. Barriers were erected to ensure that vehicles did not encroach on the exclusion zones.

For the most part, the culvert was designed as an open, free-standing U-shape, comprising cast in-situ, reinforced concrete base and walls. This configuration enabled long lengths of pipe and other equipment to be lowered into the culvert by crane. Because the roof of the culvert remained open during the fitting of pipes and equipment, the design also eliminated the hazards of manual handling and working in confined spaces. When all installation work was complete, sacrificial, pre-cast concrete formwork slabs were placed over the culvert and a cast in-situ roof was built to complete the culvert. The formwork slabs were 5,200 $\mathrm{mm}$ long, $50 \mathrm{~mm}$ deep and their width varied as required.

However this arrangement could not be used at the culvert's right angle returns. Consequently, at these locations, a fully enclosed, cast in-situ culvert was constructed. Access hatches were provided through the cast in-situ slabs. Fully enclosed sections were constructed at intervals along the straight sections to accommodate access hatches. Figure 1 shows the regions where pre-cast formwork slabs and cast in-situ slabs were used. Typical cross-sections of both types of culverts are shown in Figure 2.

\section{Figure 1: Typical culvert layout. Image @ C Blue Water Joint Venture 2009.}

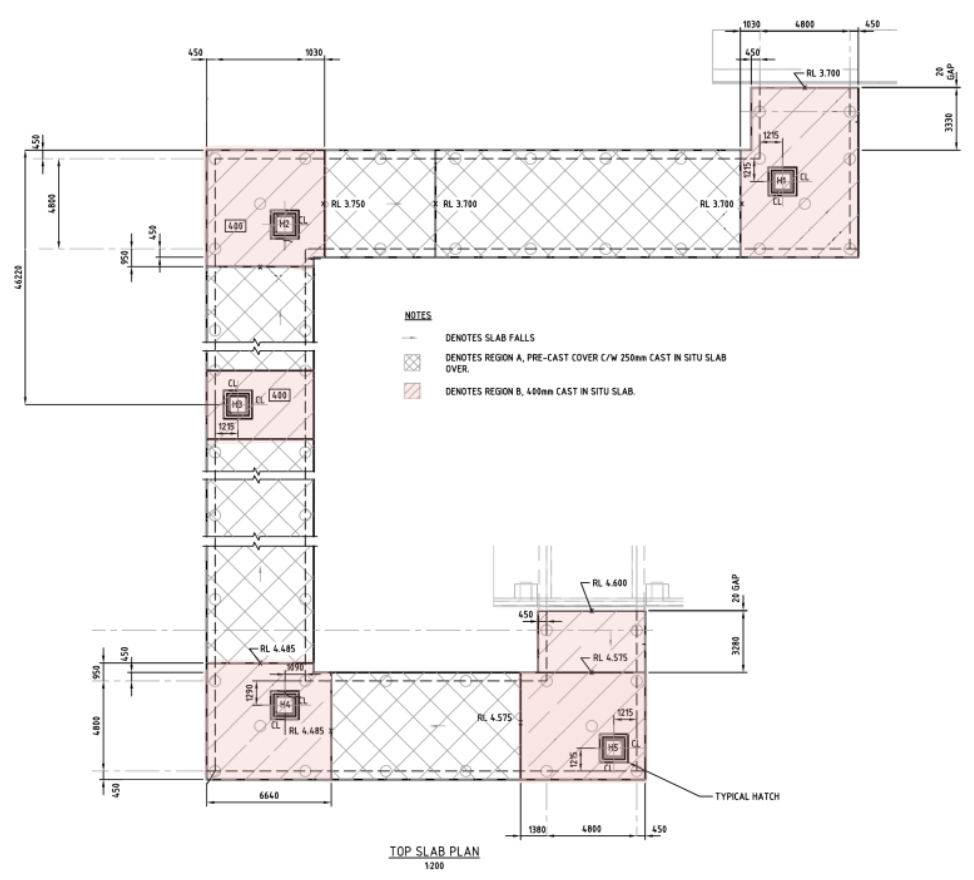


Figure 2: Typical culvert details. Image @ Blue Water Joint Venture 2009.
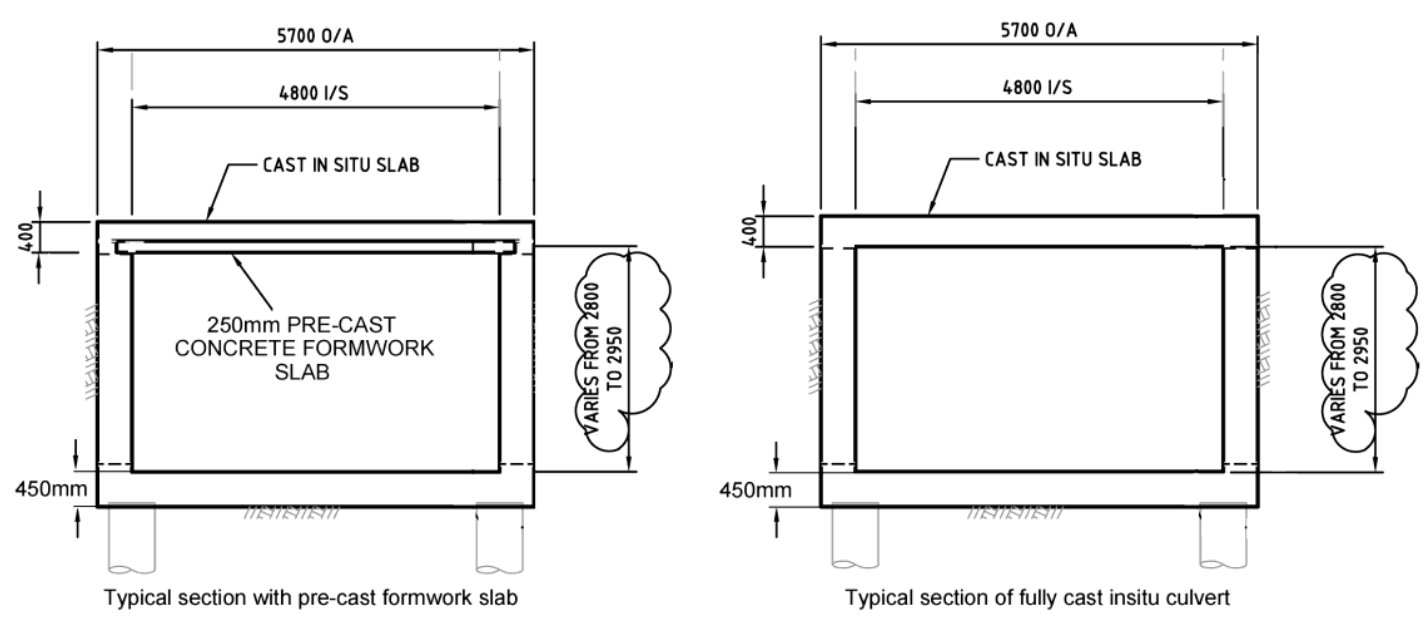

Construction of substructure for elevated road

At the freeway upgrade project, the design of the substructure supporting the elevated road incorporated PtD considerations. The substructure comprised of a pre-cast column unit is shown in Figure 3. The column units were cast in a factory and were erected with dry joints. Shear keys were provided between adjacent sections. Lifting anchors were installed in each unit and the angle of the lifting sling was specified to be not less than 45 degrees. Once the pile cap was cast, with $56 \mathrm{~mm}$ diameter stressbars protruding 1 metre above the cap, the first unit is threaded into position over the stressbars and lowered into place on the pile cap. The joint was flooded with non-shrink grout and additional units were installed after the grout has achieved a minimum strength of $25 \mathrm{MPa}$. Temporary restraint was required when three or four units were in place. Restraint was provided by installing snug tight nuts and temporary bearing plates on to the four corner bars. These nuts and plates are then removed prior to installing additional units. Once the top unit was placed, the pre-cast crosshead was installed. All pre-cast components were made under controlled factory conditions and the pre-cast solution enabled rapid on-site erection. As the construction work was taking place adjacent to an operating freeway, the method of erection took up less space, required fewer people in the construction zone and minimised the duration of exposure to OHS risks. Working platforms were fitted to crossheads, prior to erection, thus eliminating the need for scaffolding, except for gaining temporary access to the working platforms on the crossheads. Figure 4 shows a crosshead being lowered into position with the temporary working platforms attached. 
Figure 3: Column assembly details. Image () West Gate Freeway Alliance 2009.
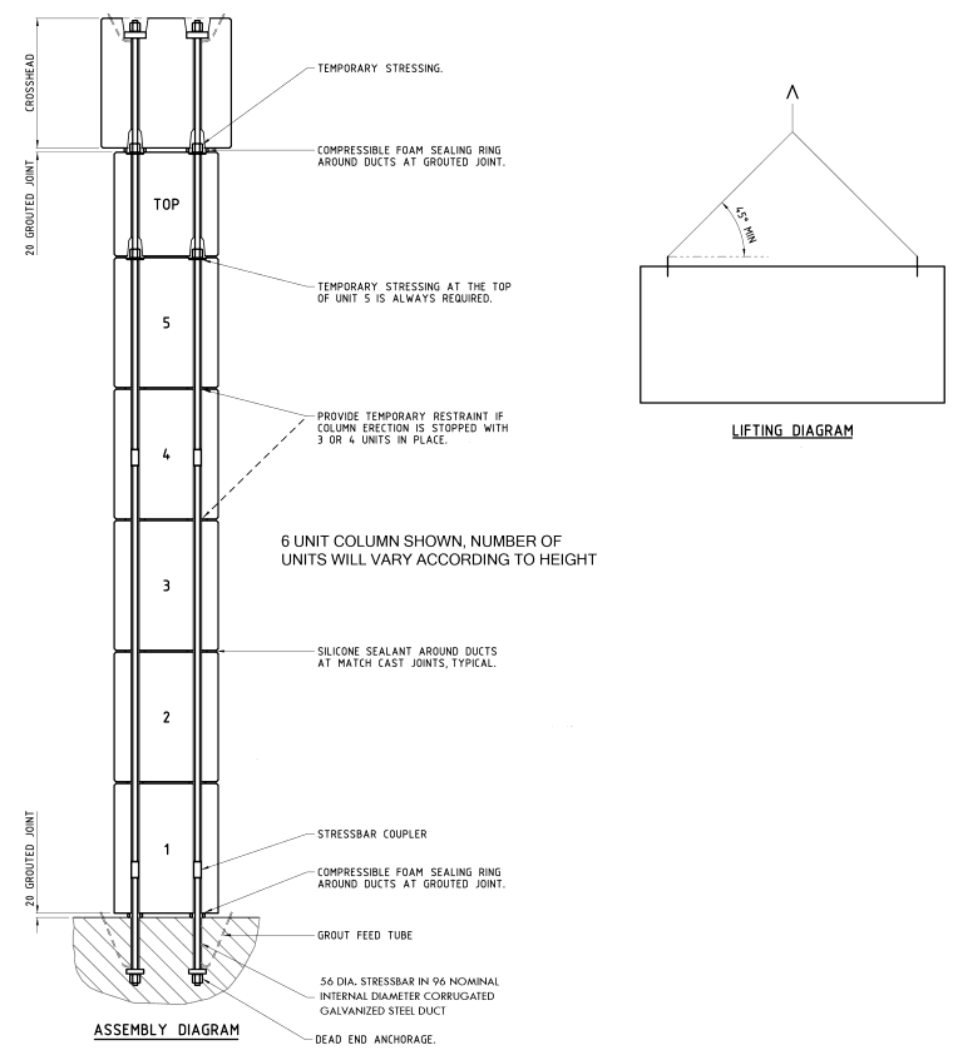

LIFTING DIAGRAM

Figure 4: Attaching the work platform to the crosshead before lifting. Image (C) West Gate Freeway Alliance 2009.

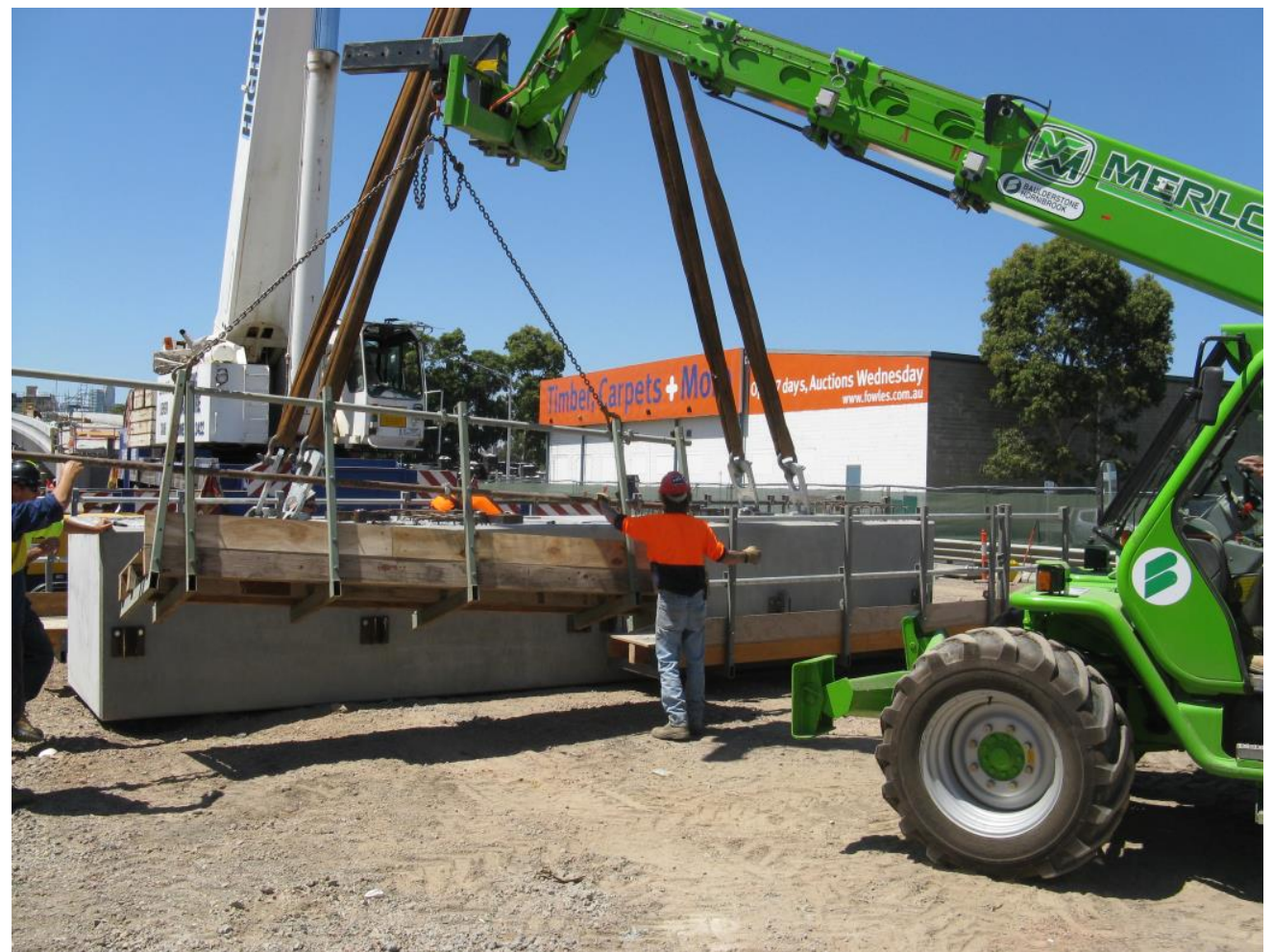




\section{Protection of openings and penetrations}

To prevent persons falling through openings and penetrations during construction of the office building, the design required all horizontal openings to be filled with mesh (see Figure 5). The mesh was then cut out when the final works are completed at the location of the penetration. The design also specified the sequencing of construction for rising works. The designers were aware that a falling hazard existed following the installation of rising air conditioning ducts. The sequencing of construction specified that block work must immediately follow the installation of ducts to eliminate the risk of falls (see Figure 6).

Figure 5: Details of mesh infill at floor penetrations. Image @ Bovis Lend Lease 2009.

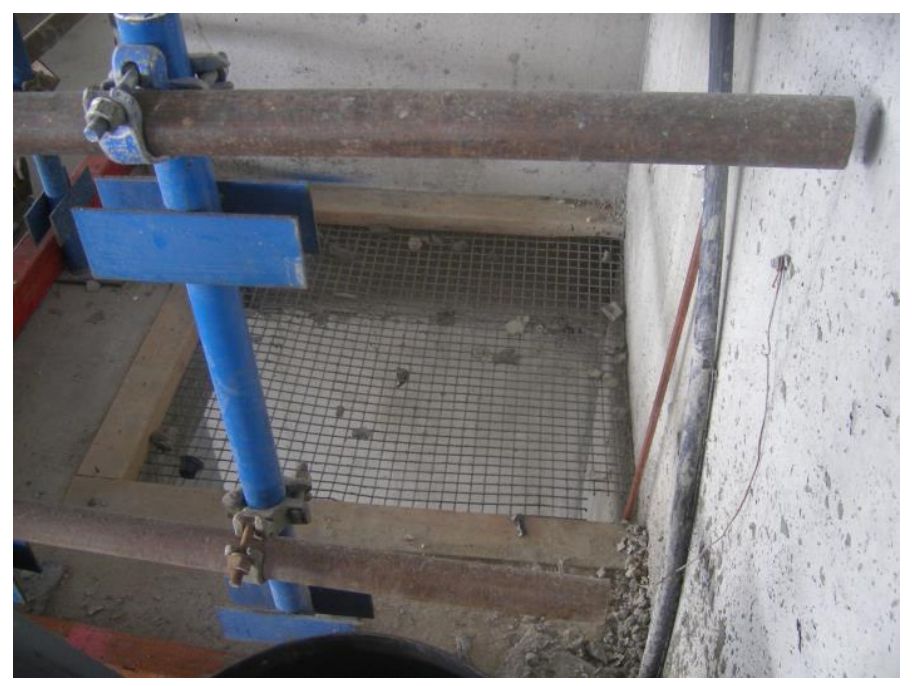

Figure 6: Protective block work installed immediately after installation of ducting. Image (C) Bovis Lend Lease 2009.

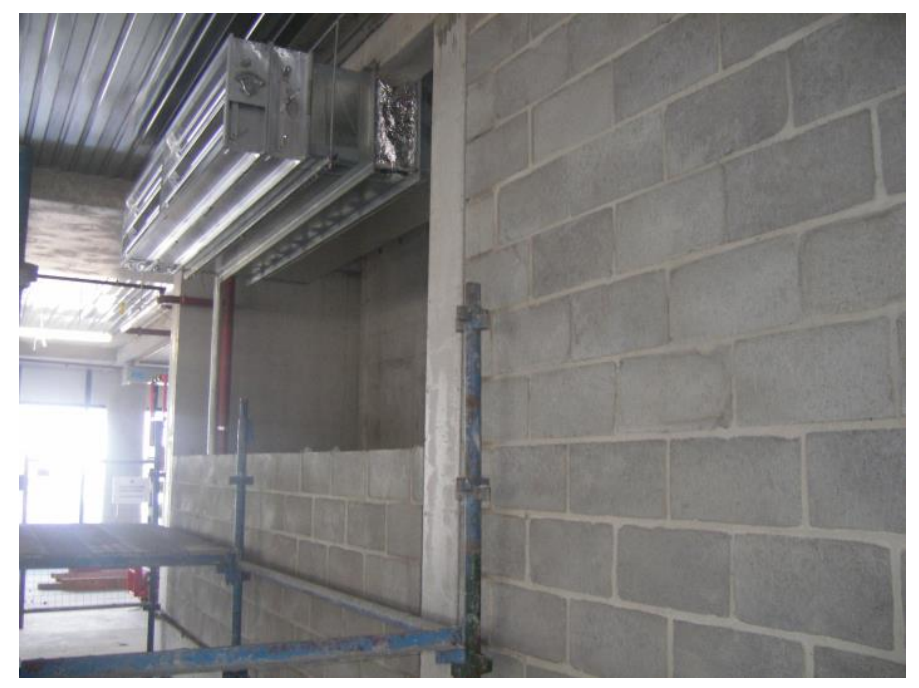

These simple but effective PtD considerations significantly reduced the risk anyone to fall through openings or penetrations during construction. The mesh provided long-term protection until the final woks at the location were completed and OHS risks were communicated to construction personnel via instructions from the designers on drawings.

\section{Discussion and conclusions}

In the two years since the Guide to Best Practice for Safer Construction was published, PtD has become an accepted practice in many large Australian construction projects. The case studies documented in the Engineering Education Australia resource kit illustrate how a systematic management process can lead to 
the implementation of design solutions that mitigate OHS risks arising during construction. In all three cases, the PtD management activities were collaborative, involving input from constructors and end users of the facilities being designed. Through national delivery of PtD training to design professionals, drawing upon the three documented case studies, Engineering Education Australia aims to further promote the Guide. The case studies and PtD resource kit were officially launched by the Victorian Minister for Roads, Ports and Major Projects, the Hon. Tim Pallas, at the CIB W099 international conference held in Melbourne in October 2009. Thus far, three one-day workshops have been delivered using the materials. More workshops will be delivered throughout Australia in 2010 and research is ongoing to evaluate the impact of the training programme upon PtD practice in the Australian construction industry.

The Guide to Best Practice for Safer Construction can be downloaded free of charge from the following website http://researchbank.rmit.edu.au/view/rmit:2663

\section{Acknowledgement}

The authors would like to thank Ann Ellis of Engineering Education Australia for her support in the development of the PtD resource kit. Grateful thanks are also extended to personnel at the case study projects who provided time and information enabling the development of the case studies, and to $\mathrm{Mr}$ David Jellie who assisted in documenting the case studies.

\section{References}

Australian Safety and Compensation Council (2008), Information Sheet, Construction, ASCC, Canberra.

Behm, M, (2005), Linking construction fatalities to the design for construction safety concept, Safety Science, 43, 589611.

Creaser, W., (2008), Prevention through Design (PtD) Safe Design from an Australian Perspective, Journal of Safety Research, $39,2,131-134$

Driscoll, T. R., Harrison, J. E., Bradley, C. \& Newson, R. S., (2005), Design issues in work-related serious injuries, Department of Employment and Workplace Relations, Commonwealth of Australia, Canberra.

Driscoll, T. R., Harrison, J. E., Bradley, C. \& Newson, R. S., (2008), The Role of Design Issues in Work-Related Fatal Injury in Australia, Journal of Safety Research 39, 209-214

Fleming, T, Lingard, H \& Wakefield, R 2007a, Guide to best practice for safer construction: Principles, Cooperative Research Centre for Construction Innovation, Brisbane.

Fleming, T, Lingard, H \& Wakefield, R 2007b, Guide to best practice for safer construction: Tasks, Cooperative Research Centre for Construction Innovation, Brisbane.

Gambatese, J. A., Behm, M. \& Rajendran, S., (2008), Design's role in construction accident causality and prevention: Perspectives from an expert panel, Safety Science 46, 675-691.

Gibb, A., Haslam, R., Hyde, S. \& Gyi, D., (2004), The role of design in accident causality, in: Designing for safety and health in construction: Proc., Research and Practice Symposium, S. Hecker, J. Gambatese, and M. Weinstein, eds., UO Press, Eugene, Oregon.

Manuele, F. A., (2008), Prevention through Design (PtD): History and Future, Journal of Safety Research 39 (2008) $127-130$

National Occupational Health and Safety Commission 2002, National OHS Strategy 2002-2012, Commonwealth of Australia, Canberra.

Suraji, A., Duff, A.R. \& Peckitt, S.J. (2001), Development of a causal model of construction accident causation, Journal of Construction Engineering and Management, 127, 337 - 345.

Toole, M. T., (2005), Increasing engineers' role in construction safety: Opportunities and barriers, ASCE Journal of Professional Issues in Engineering Education and Practice, 131, 199-207.

Toole, M. T., Design Engineers' Responses to Safety Situations, Journal of Professional Issues in Engineering Education and Practice, 133, 126-131

WorkCover New South Wales, (2001), CHAIR: Safety in design tool, Sydney. 